Research

\title{
Farmers' agricultural tractor preferences in Ethiopia: a choice experiment approach
}

\author{
Wubamlak Ayichew Workneh ${ }^{1}$ (D) Kiyokazu Ujiie ${ }^{2} \cdot$ Shusuke Matsushita $^{2}$
}

Received: 2 February 2021 / Accepted: 2 March 2021

(C) The Author(s) 2021 OPEN

\begin{abstract}
Unless supported by agricultural mechanization, achieving sustainable development goals is generally challenging in sub-Saharan African countries, specifically so in Ethiopia. Animal power is the dominant mode for plowing, threshing, and transportation in Ethiopia and yet, at the same time little effort was employed to assess subsistence farmer's tractor demand in the study area. This study was conducted to understand the preferences of wheat producer subsistence farmers for agricultural tractors in Ethiopia in 2017. A random sample of 79 households participated in either rental or purchase choice experiments. The descriptive statistics revealed that $42 \%$ of respondents chose to buy tractors, and $43 \%$ preferred to use rental services. The random parameter logit estimation result showed that plowing-and-transporting tractors were preferred by the farmers who participated in the purchase design. They are also willing to pay ETB 149,142 (USD 6516) for transporting-only tractors, ETB 218,253 (USD 9536) for plowing-only tractors, and ETB 367,957 (USD $16,077)$ for plowing-and-transport-only tractors. However, due to the exclusion of high wheat producers in the rent experiment, the current rental price was found to be far from the $99 \%$ confidence interval of the estimated price. The government should promote and encourage the appropriate use of agricultural tractors that are affordable for subsistence farmers through rental or purchase. Conservative agriculture should also be practiced as the over-use of tractors may disrupt biodiversity and natural biological process.
\end{abstract}

Keywords Choice experiment · Mechanization · Subsistence farming · Sustainable Development Goals · Tractors

\section{Introduction}

Agriculture in Africa, particularly in Ethiopia, is dominated by subsistence farming, in which a family produces only to feed themselves [1, 2]. Further, such farming is the main source of employment; that is, most of the population is involved directly or indirectly, including $75 \%$ of the population in sub-Saharan Africa (SSA) countries and $80 \%$ in Ethiopia $[3,4]$. However, because of the inefficient technologies employed, production and productivity are very low.

Eradicating poverty, attaining zero hunger, and ensuring responsible consumption and production are elements of the 17 Sustainable Development Goals (SDGs) adopted by all United Nations (UN) member states in 2015; these goals are expected to be achieved by 2030 [5]. However, accomplishing the SDGs is challenging in SSA countries, as these economies are mostly dependent on subsistence agriculture. The introduction of mechanization to the agricultural production system plays a beneficial role in achieving SDGs by increasing food production through land-intensive agriculture. Mechanization also expands farmers' sources of cash income by shortening the land preparation period, which allows them to become involved in other income-generating activities (IGAs).

Wubamlak Ayichew Workneh, wubamlak@gmail.com | ${ }^{1}$ Graduate School of Life and Environmental Sciences, University of Tsukuba, Tsukuba, Japan. ${ }^{2}$ Faculty of Life and Environmental Sciences, University of Tsukuba, Tsukuba, Japan.

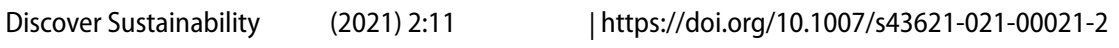


The introduction of plowing machinery, in particular, can shorten the land preparation period, which would otherwise take half a year. Farmers can then start to use their lands more intensively by producing more than one yield per year, given the availability of water sources and other inputs. Land-intensive agriculture is expected to boost production scale and productivity, which helps to improve household income. Land-intensive agriculture also promotes labor-intensive agriculture that can improve labor productivity.

Additionally, the introduction of tractors is expected to shorten the land preparation period, which can give farmers time to engage in IGAs to improve their incomes. Income diversification is one of the major coping strategies for subsistence farmers in cases of crop failure.

The government of Ethiopia planned to promote agricultural tractors to reduce post-harvest losses from 20 to $5 \%$ and to increase the magnitude of its mechanical power index to $3.35 \mathrm{hp} / \mathrm{ha}$ by 2022 [6]. An agricultural mechanization strategy has also been designed to increase national food production and security through enhanced and sustainable use of agricultural mechanization technologies to support Ethiopia's middle-income status by $2025[7,8]$.

Labor-intensive agriculture is one of the strategies designed by the Agricultural and Rural Development (ARD) Policy of Ethiopia. However, overpopulated sectors diminish the returns of additional labor, ultimately causing a low wage rate in those sectors. One of the shortcomings of the ARD policy is that it does not consider the daily farming practices of subsistence farmers in Ethiopia [9]. Subsistence farmers need more labor only during the weeding and harvesting periods, which take a day each. Land preparation requires a 2:1 ratio of animal power and human labor, where animal power is the binding factor for subsistence farmers. Each unit of human labor added to the agriculture sector requires at least one pair of oxen to plow. Otherwise, additional labor does not add any value to the current production system because land preparation is the most time-consuming activity. The ongoing labor-intensive agriculture aggravates unemployment more than it boosts production and productivity. Seasonal labor-intensive agriculture on subsistence farms has created seasonal labor unemployment, which results in low annual incomes for these families. Therefore, promoting improved agricultural technologies and short-cycled improved seeds will encourage land-intensive agriculture, which, in turn, promotes labor-intensive agriculture. In addition, farmers will gain the opportunity to become involved in other IGAs to diversify their income sources [10].

However, despite the benefit of agricultural tractors and the shortcomings of animal power, subsistence farmers continue to use animal power for plowing, threshing, and transportation. This is because of limited access to mechanization in the study area. Therefore, this research was designed to identify how subsistence farmers can access agricultural tractors to improve production and productivity.

Efforts exerted to understand the demand of agricultural tractors in the study area were not enough. Therefore, this study investigates the preferences of wheat producer farmers in terms of adopting wider use of agricultural tractors and to understand how subsistence farmers can access modern farm implements in the Debre Eliyas district in Ethiopia.

Using various approaches, studies have demonstrated that the adoption of agricultural tractors contributes to improving productivity and minimizing the unit cost of crop production [11]. Moreover, farmers are willing to adopt agricultural tractors, depending on their demographic characteristics, economic condition, and access to extension services [12, 13]. Further, the type and method of adoption differ depending on the multifunctionality of the tractor and the economic status of the adopter [14]. This study employed a choice experiment approach to investigate the preferences of subsistence farmers for alternative agricultural tractors, assuming a heterogeneous society. This finding contributes to enhancing our understanding of the application of the stated preference approach to technology adoption. The study also supports the Ethiopian national mechanization strategy by proposing tractor adoption strategies and presenting the market demand in the country.

\section{Methodology}

\subsection{Study area}

Subsistence farmers in Ethiopia have been using the oxen-plow since 1939 [15]. The technology was introduced by Italian farmers, and it works by using two oxen to pull a tiller that is supported by a human operator. It takes $24 \mathrm{~h}$ to plow one ha, although a four-wheeled tractor can accomplish this in $3 \mathrm{~h}$ and $12 \mathrm{~min}$.

As discussed by Cohen [16], mechanization in Ethiopia started during the emperor's regime as a response to the outbreak of famine in 1958. The Chilalo Agricultural Development Unit and Welayita Agricultural Development Unit were the first agricultural development units created to demonstrate mechanization in the country [16]. In 1984, the Nazareth 
Tractor Assembling Plant was established in collaboration with the USSR to promote the wider use of agricultural machinery. However, mechanization is still at the lowest stage: only large-scale farmers are using powered engine tractors. An estimated 5,090 tractors were operating in the country by 2010 . Furthermore, the number of tractors imported into the country increased to around 12,231 in $2015[17,18]$. However, the magnitude of the mechanical power index per hectare remained very low: $0.1 \mathrm{kw} / \mathrm{h}$. The number of tractors per $100 \mathrm{~km}^{2}$ is 2.24 [8]. The Ethiopia Strategy Support Program research note number 48 indicates that, among the survey of 5,969 households in the country, only $5.5 \%$ used machinery for plowing either in 2014 or 2015.

A choice experiment was conducted for two alternatives, four-wheeled tractors (4WT) and two-wheeled tractors (2WT), with respect to the oxen-plow in the Debre Eliyas district in Ethiopia. The Debre Eliyas district is one of the major wheat producing areas and is located in the northwest part of Ethiopia. The district can be classified into two agricultural zones based on wheat productivity. Zone I has six kebeles [wards] and is classified as a high wheat production area, where the productivity reached six tons per hectare. Zone II consists of 10 kebeles. It is regarded as a low wheat production area, where the productivity is only 3.6 tons per hectare. Based on zonal differences in wheat productivity, we also tried to understand the heterogeneity of preferences for tractors of different types and means of adoption.

Land preparation in the study area began at the beginning of March and extended at the end of July, whereas harvesting took place from early September through late December (Fig. 1). Land preparation takes much of subsistence farmers' energy and time because of inefficient technologies employed [19, 20]. As a result, subsistence farmers in the study area, and throughout Ethiopia, are producing agricultural products once per year.

Currently, wheat producers in the study area have begun using rental tractors and combined harvesters for plowing and harvesting. According to the office of agriculture in the district, they pay Ethiopian Birr (ETB) 2000 (USD 87) per ha for plowing and ETB 70 (USD 3) per quintal for harvesting. However, most of the rental service suppliers are large-scale farmers who have their own farmland and are located mostly in the southern part of Ethiopia. Moreover, tractor dealers are located in Addis Ababa, Mekele, and Adama, which are more than $300 \mathrm{~km}$ from the study area. Therefore, even though the demand for tractors is increasing, the supply is very limited. Nowadays, the government has started to use organized youth groups to introduce rental tractors in the area. However, even though these groups were organized, and have saved the required amount of cash in the bank, the government has failed to distribute the required type and number of tractors to these groups.

The study area was selected for its typical atmospheric, geographic, and demographic characteristics for Ethiopia and SSA countries as well. It has a rainy season and dry season, as all SSA countries have. Agriculture is dominated by subsistence farming with the country's younger labor force. Wheat is one of the major crops produced there. Ethiopia is one of the SSA countries contributing to global wheat production. SSA countries account for $40 \%$ of wheat production in Africa and $1.4 \%$ of global wheat production [21].

\subsection{Empirical model selection}

We applied a choice experiment to identify farmers' preferences over a set of hypothetically constructed alternative tractors with given prices. This approach has mostly been used to identify consumer preferences. However, this approach is also applicable to assess farmers' technology adoption.

First, because of incomplete markets in rural areas, farmers must make production and consumption decisions simultaneously. Imperfections in rural markets compel farmers to jointly decide profit and utility maximization [22]. Therefore, the consumption decision can be expected to affect the production decision directly [23]. The decision to consume

\begin{tabular}{|c|c|c|c|c|c|c|c|c|c|c|c|c|}
\hline & Jan & Feb & Mar & Apr & May & Jun & Jul & Aug & Sept & Oct & Nov & Dec \\
\hline \multicolumn{13}{|c|}{ Land preparation } \\
\hline \multicolumn{13}{|l|}{ Planting } \\
\hline \multicolumn{13}{|l|}{ Weeding } \\
\hline \multicolumn{13}{|l|}{ Harvesting } \\
\hline Threshing & & & & & & & & & & & & \\
\hline
\end{tabular}

Fig. 1 Agricultural activities 
leisure time will affect decisions about how much labor contributes to production [24]. The machinery we are proposing to farmers is labor-saving machinery that is directly related to leisure-time consumption and labor contributions to production. Furthermore, the amount of grain to consume is dependent on the amount of grain produced, which is directly related to farmland productivity and the area used for production. Therefore, because of the non-separability of consumption and production decisions in rural markets when imperfect markets exist, applying a choice experiment is a reasonable means of assessing farmers' behavior.

Second, the model and choice experiment can be used as an ex-ante evaluation technique before the introduction of new agricultural technologies. A revealed preference approach measures the farmers' actual decisions related to given technologies. Technology adoption will be decided based on the aggregated demand and market clearing price over the given population. Furthermore, an endogeneity problem exists between the variables in the model and the adoption level [25]. In addition, in cases of technology adoption trials, the cost of conducting a revealed preference approach will be high if the technology fails to be chosen by the farmer. Measuring actual farmers' decisions is a type of impact evaluation of the actual technology. The stated preference approach provides more flexibility because of the nonexistence of the technologies presented in the survey. It helps to construct hypothetical alternatives that do not actually exist [26]. In this case, we will not have actual costs, even though the hypothetically constructed technologies are not chosen.

The target of the study is an ex-ante (need assessment) evaluation that measures the expected benefits of the technology before its introduction to the farmers. We can use focus group discussions, key informant interviews, community meetings, and surveys to assess the needs of target beneficiaries. Each technique is applicable, either separately or collectively, for a single study based on the deliverables planned. In our case, because of individual characteristics, land fertility, and size differences, we assumed heterogeneity of preferences. For these reasons, we applied a survey (choice experiment) to understand the preferences of farmers for agricultural tractor adoption. We used focus group discussions and key informant interviews to select the attributes that were used [27]. Many researchers have applied this model to farmers' behavior [28-30].

\subsection{Choice experiment design}

We used focus group discussions, key informant interviews, and literature reviews to select relevant attributes and levels for the design. The tractor purchase design and rental service design had four and three attributes, alternatively (Fig. 2, Tables 1, 2).

The definitions of the attributes are presented as follows.

a. Type of tractor: In the study area, plowing one ha using animal power requires $24 \mathrm{~h}$, and 3:12 $\mathrm{h}$ and $10: 30 \mathrm{~h}$ is sufficient for $4 W T$ and $2 W T$, respectively. The respondents valued the time and human effort saved because of tractor adoption. Therefore, the attribute, type of tractor, was selected in the purchase-design because of the efficiency differences between $2 W T$ and $4 W T$, which are the two levels of this attribute.

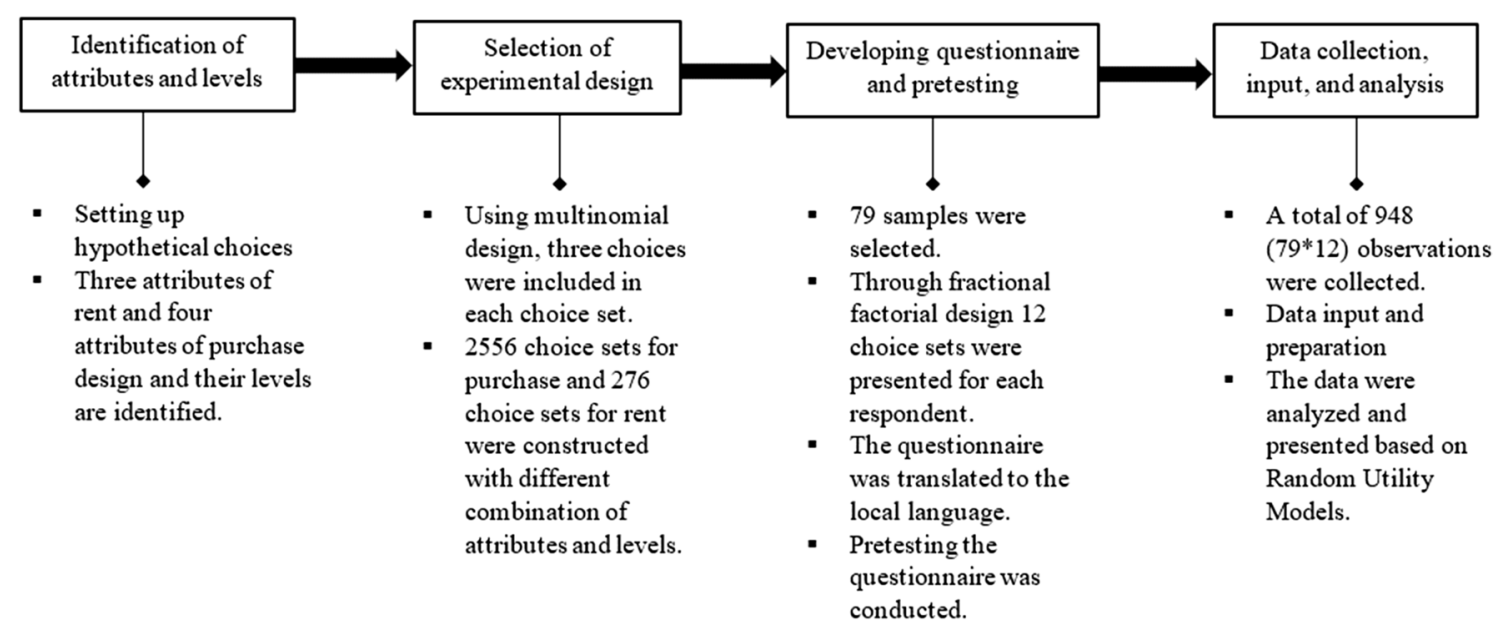

Fig. 2 Research framework 
Table 1 Attributes and levels of own-tractor purchase design

\begin{tabular}{|c|c|c|c|}
\hline & Attributes & Levels and codes & Definitions \\
\hline \multirow[t]{2}{*}{1} & Type of tractor & 1. Four-wheeled (FW) & Four-wheeled tractor, having four wheels, can plow 1 ha in $3: 12 \mathrm{~h}$ \\
\hline & & 2. Two-wheeled (TW) & $\begin{array}{l}\text { Two-wheeled tractor, having two wheels only, the operator walks } \\
\text { while plowing }(10: 30 \mathrm{~h} / \mathrm{ha})\end{array}$ \\
\hline \multirow[t]{2}{*}{2} & Condition & 1. New $(\mathrm{N})$ & New tractor that has never been used before \\
\hline & & 2. Used (U) & A tractor used by other farmers not more than 10 years \\
\hline \multirow[t]{3}{*}{3} & Multi-functionality & 1. Plowing only (PO) & The machine can be used only for plowing \\
\hline & & 2. Transport only (TO) & The machine can be used only for transporting goods \\
\hline & & 3. Plowing and transport (PTO) & The machine can be used for both plowing and transporting services \\
\hline 4 & Price $(P)$ & $\begin{array}{l}\text { 1. ETB } 45,000 \\
\text { 2. ETB } 60,000 \\
\text { 3. ETB } 75,000 \\
\text { 4. ETB } 90,000 \\
\text { 5. ETB } 105,000 \\
\text { 6. ETB } 120,000\end{array}$ & Average purchase price per machine in ETB ( 1 USD = 22.8874 ETB) \\
\hline
\end{tabular}

Table 2 Attributes and levels of rental service design

\begin{tabular}{|c|c|c|c|}
\hline & Attributes & Levels and codes & Definition \\
\hline 1 & Time duration & $\begin{array}{l}\text { 1. } 3.2 \mathrm{~h} / \mathrm{ha}(3: 12 \mathrm{~h})(\mathrm{FW}) \\
\text { 2. } 10.5 \mathrm{~h} / \mathrm{ha}(10: 30 \mathrm{~h})(\mathrm{TW})\end{array}$ & $\begin{array}{l}\text { Length of time taken to plow } 1 \text { ha with four-wheeled tractor } \\
\text { Length of time taken to plow } 1 \text { ha with a two-wheeled tractor }\end{array}$ \\
\hline 2 & Payment Period & $\begin{array}{l}\text { 1. On-time }(\mathrm{OT}) \\
\text { 2. After harvest }(\mathrm{AH})\end{array}$ & $\begin{array}{l}\text { Payment is made immediately after obtaining the service } \\
\text { Payment is made after the harvest season }\end{array}$ \\
\hline 3 & Rental price (Rp) & $\begin{array}{l}\text { 1. ETB } 1200 \\
\text { 2. ETB } 1400 \\
\text { 3. ETB } 1600 \\
\text { 4. ETB } 1800 \\
\text { 5. ETB } 2000 \\
\text { 6. ETB } 2200\end{array}$ & Rate for plowing 1 ha with the same quality $(1 \mathrm{USD}=22.8874 \mathrm{ETB})$ \\
\hline
\end{tabular}

b. Condition: The second attribute in the purchase-design is the tractors' current condition (either new or used). It was included in the design because of the price and service year differences between the two levels.

c. Multifunctionality: The third attribute in the purchase-design was selected based on the services associated with each tractor. Farmers in the study area use animal power for plowing, threshing, and transportation. Therefore, farmers need tractors that can provide multiple services in addition to plowing. Transporting only, plowing only, and plowing and transporting only tractors are included in this attribute as levels.

d. Time duration: The time required to plow one ha with the same quality is the major decision variable during peak seasons of land preparation as it creates significant differences in the adoption level. It depends on the type of tractor employed in the rental service and is represented by the time duration attribute in the rent-design.

e. Payment period: This attribute was selected to create alternative payment options to solve cash constraints during the planting and sowing seasons. As there are expenditures for fertilizer, improved seeds, and other items during the planting season, the after-harvest alternative payment option was used in the experiment in addition to on-time payment.

f. Price: Finally, the price attribute was included because of its effect on the demand for tractor adoption in both designs. Farmers make decisions by comparing the costs of using machinery and animal power. In the purchase-design, the price indicates the unit price for each tractor, and in the rent-design, it shows the price of plowing a hectare of farmland. In addition, it is also used to evaluate the ability to pay for purchasing and rental services. 


\subsection{Random parameter logit}

The random parameter logit model was used to capture heterogeneity across respondents [31-33]. Because of individual characteristics, each decision-maker may have different preferences for alternative farming machinery. Regarding purchase design, hypothetical alternatives were created based on the efficiency, condition, multifunctionality, and unit price of the tractor. The same case was applied for rent design using the efficiency, payment mode, and rental price per hectare.

The utility of farmer ' $n$ ' choosing from $J$ alternative tractors can be estimated as presented below.

$$
\begin{gathered}
U_{n j}=V_{n j}+\varepsilon_{n j} \\
V_{n j}=A S C+\sum_{k \in\left\{T W, A H, P_{R}\right\}} \beta_{n j k} x_{n j k}+\varepsilon_{n j} \\
V_{n j}=A S C+\sum_{k \in\left\{F W, P O, U, P T O, T O, P_{P}\right\}} \beta_{n j k} x_{n j k}+\varepsilon_{n j}
\end{gathered}
$$

where

$x_{n j k}=\left(T W, A H, P_{R}\right)$ : in the case of rent design, and.

$x_{n j k}=\left(F W, U, P O, P T O, T O, \mathrm{P}_{P}\right)$ : in the case of purchase design.

$T W, A H, O T, F W, U, N, P O, P T O$, and $T O$ are alternative characteristics that take a dummy value (" 1 " for the presence of the variable, and " 0 " otherwise). $\beta_{n j k}$ is a vector of individual-specific preference parameters that capture heterogeneity across respondents, and $\varepsilon_{n j}$ is the stochastic utility unobserved by the researcher with independent and identically distributed extreme value.

The alternative specific constant (ASC) took the values of the bases $\left(\beta_{0}\right)$ of each experiment. We assumed a rental service company using a $4 W T$ to plow farmland with acceptable quality and an on-time cash payment mode as a base for rent design, and we assumed a new $2 W T$ with transporting service only as a base for purchase design. Therefore, the value of the ASC shows the farmers' decision to buy a new $2 W T$ for transporting service in the purchase-design, whereas in the rent design, it shows the farmers' willingness to accept a rental service for a $4 W T$ with on-time payment.

The stochastic part of the utility is correlated with the alternative tractors. Moreover, the model does not exhibit the independent from irrelevant alternatives (IIA) property of the standard logit. For this model, we assumed that each farmer has a different taste for each characteristic of the alternative tractors.

We cannot estimate the probability using the standard logit specification because $\beta_{n}$ s are not fixed. If $\beta_{n}$ s are known, and if they have a value of $\beta$, then the probability can be estimated using a standard logit specification, as shown below.

$$
\begin{gathered}
P_{n j}=\frac{e^{\beta_{n j k} x_{n j k}}}{\sum_{j=1}^{J} e^{\beta_{n j k} x_{n j k}}} \\
P_{n N F P T O}=\frac{e^{A S C+\beta_{n F W} F W+\beta_{n P T O} P T O+\beta_{n P_{R}} P_{R}}}{\sum_{j=1}^{J} e^{\beta_{n j k} x_{n j k}}}
\end{gathered}
$$

NFPTO stands for New, 4WT, and Plowing and Transport only tractor.

However, the exact value of each farmer's taste, $\beta_{n}$, is not known because it varies among decision-maker farmers with density $f\left(\beta \mid \theta^{*}\right)$, where $\theta *$ is the mean and standard deviation. Then, the probability of selecting a tractor can be estimated by the integral of (3) with a density of $\beta$, as shown below.

$$
Q_{n i}\left(\theta^{*}\right)=\int P_{n i}(\beta) f\left(\beta \mid \theta^{*}\right) d \beta
$$

For the maximum likelihood estimation, one can use the sequence of choice for each farmer over the given choices of alternative tractors. If the value of $\beta$ is known, then the sequence of probability is 


$$
S_{n}(\beta)=\prod_{j=1}^{J} P_{n j}(\beta)
$$

However, we do not know the value of $\beta$. Therefore, the probability is the integral of (6) with the distribution function.

$$
P_{n}\left(\theta^{*}\right)=\int S_{n}(\beta) f\left(\beta \mid \theta^{*}\right) d \beta
$$

Even though the exact maximum likelihood estimation cannot be derived from $L L(\theta)=\sum_{n} \ln P_{n}(\theta)$, we can approximate by drawing the random values of $\beta$ from Eq. (6) using simulation [33].

$$
S P_{n}(\theta)=\left(\frac{1}{R}\right) \sum_{r=1, \ldots, R} S_{n}\left(\beta^{r \mid \theta}\right)
$$

where $R$ is the number of draws of $\beta$, and $\theta$ is the mean and covariance of the distribution function.

Finally, the simulated log-likelihood function will be:

$$
\operatorname{SLL}(\theta)=\sum_{n} \ln \left(S P_{n}(\theta)\right)
$$

The willingness to pay was estimated using the coefficients of non-monetary attributes $\beta_{m}$ and the price coefficient $\beta_{p}$.

$$
W T P_{m}=-\left(\frac{\beta_{m}}{\beta_{p}}\right)
$$

Here, $m$ represents the non-monetary attribute, and $p$ denotes the price attribute.

In the estimation process, different packages of $R$ were used, yielding results similar to those presented in Tables 6 , 8. First, a standard logit model was applied with the clogit package, assuming homogeneous respondents. Second, the heterogeneity of the respondents was recognized. The variables (levels of the attributes) were assumed to be random with a normal distribution across the population. Finally, the ASCs of both the rental-design and purchase-design were assumed to be random with a normal distribution (Tables 6, 8). The packages mlogit [34], survival [35], and gmnl [36, 37] were used with $R$. In all cases, the estimated results gave the same meanings over the variable, as presented in the next section.

\subsection{Data collection}

The design and questionnaire, developed using $R$ with support. CE package [38] were used for the survey. By combining the attributes and levels in Tables 1, 2, we constructed $a^{b} * c^{d}$ possible choice scenarios where $a$ and $c$ are different attribute levels, and $b$ and $d$ are different attributes [26]. For the purchase-design, we got two attributes with two levels, one attribute with three levels, and one attribute with six levels. Then, the number of possible choices will be $2^{2} \times 3^{1} \times 6^{1}=72$. However, the questionnaire was presented with two choices and one opt-out option. Therefore, with different arrangements of the possible scenarios, the number of choice sets became $72 \times 71 / 2=2556$, which is called the full factorial design. The same steps were applied for the rent design and found 276 choice sets $\left[\left(2^{2} \times 6^{1}\right) \times(23) / 2\right]$. However, it was not manageable to present the full factorial choice sets in the survey. Instead, choice sets were reduced to a fractional factorial design comprised of 36 choice sets for purchase design and 12 choice sets for rent-design that satisfy orthogonality and level balance [26]. The 36 choice sets of purchase-design were divided further into three blocks with 12 choice sets each. Each choice set has two generic alternatives and an "opt-out" option (representing oxen-plow) (Fig. 3). In addition to the 12 choice sets, socioeconomic and demographic characteristics were included in the questionnaire and presented for each respondent. Two rounds of pretests were conducted on a total of 15 respondents prior to organizing the final survey. The first pretest was conducted on the last week of February and the second at the end of April and found better consistency among them that shows the validity and reliability of the questionnaire.

Before the survey, a detailed explanation of the survey and its objective was presented, supported by pictorial representation (Fig. 3a-d). An explanation of the type, benefit, similarities, and differences of each tractor was provided based on the guiding checklists. To minimize information heterogeneity across respondents, all explanations about the survey were given in groups. Finally, a discussion session was given to the respondents to understand their experiences 
Fig. 3 Sample choice set

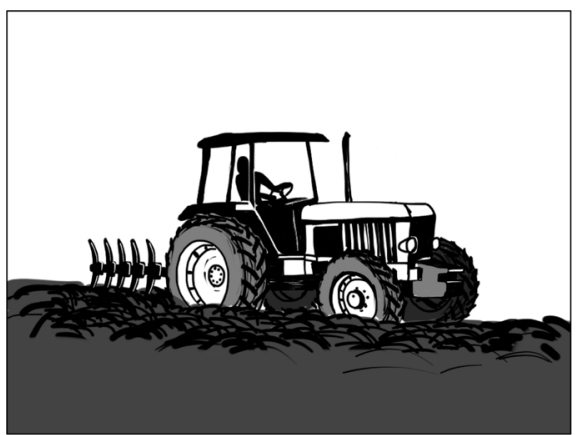

(A) Plowing only four-wheeled tractor

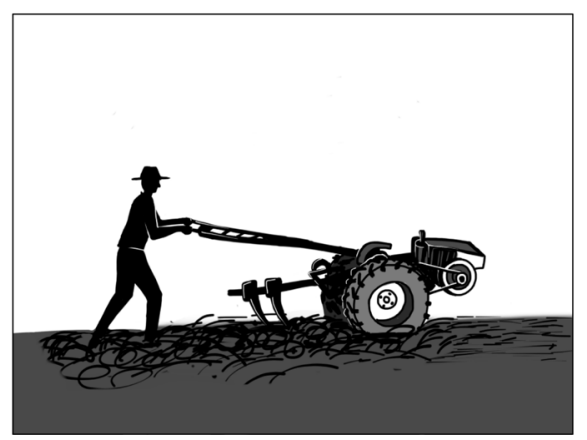

(C) Plowing only two-wheeled tractor

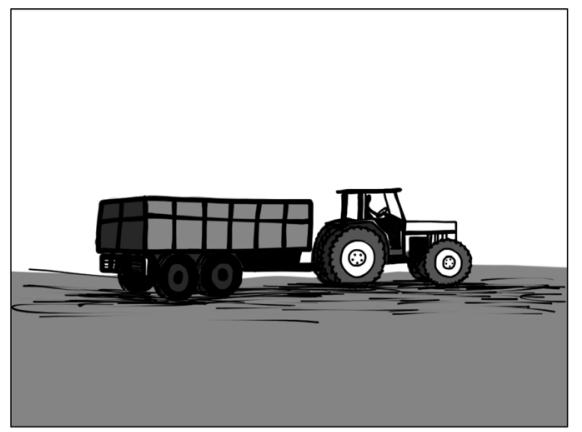

(B) Transporting only four-wheeled tractor

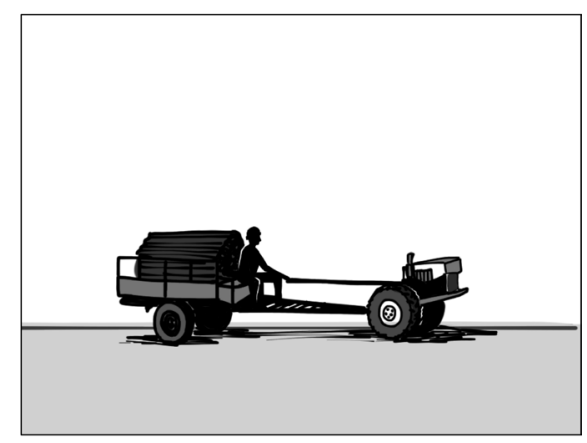

(D) Transporting only two-wheeled tractor

\begin{tabular}{l|l|l}
\hline Attributes & Tractor 1 & Tractor 2 \\
\hline Efficiency & Two-wheeled & Four-wheeled \\
Condition & New & Used \\
Multifunctionality & Plowing and Transport & Transport only \\
Price (ETB) & 60,000 & 80,000 \\
\multicolumn{2}{|c}{$\square$ I prefer alternative 1. } \\
\multicolumn{1}{c}{$\square$ I prefer alternative 2. } \\
\end{tabular}

(E) Choice set

and views about the tractor. Checkup questions were included in the questionnaire to check if the respondents were answering logically.

A multi-stage sampling technique was used to select respondents from the study area. Kebeles were grouped into two zones: high-wheat producing and low-wheat producing kebeles. Then, systematic random sampling was used to select six representative kebeles (Fig. 4). Finally, random sampling was applied to select respondents from each kebele. Then, each respondent was asked to choose from tractor purchase, rental service, or continued use of an oxen-plow. From 13,117 target households (1084 are women headed), a total of 79 respondents participated in the survey. Of these respondents, 33 responded to purchase design and 35 for rent design, and the remaining 11 respondents chose to keep using an oxen-plow. The survey was conducted between May 13 and June 14, 2017 in the Debre Eliyas district in Ethiopia.

\section{Results and discussion}

\subsection{Descriptive statistics}

The variable definitions are provided in Table 3. From the descriptive statistics, Table 4, we can see that a farm, $\mathrm{HH}$, has an average of six members and two ha of farmland. They also have an average of four oxen. The main source of income is agriculture, and the major product is wheat. All of them have information about tractor use, and $2.5 \%$ of 
Fig. 4 Map of the study area
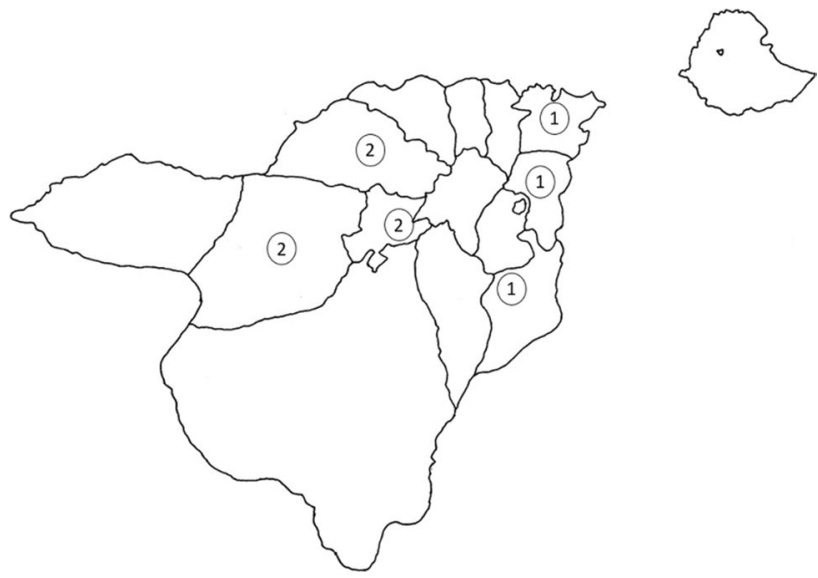

Table 3 Variable definitions

\begin{tabular}{|c|c|c|}
\hline & Definition & Unit \\
\hline HH head & Household head (Male $=1$, Female $=0$ ) & Dummy \\
\hline Type of farmer & Type of farmer (Model farmer $=1$, otherwise $=0$ ) & Dummy \\
\hline Family size & Number of family members & Number \\
\hline Working family size & Number of working family members & Number \\
\hline Information on tractor use & Have heard about tractor $=1$, otherwise $=0$ & Dummy \\
\hline Own farm size & Size of owned farm size & Hectare \\
\hline Rented farm size & Farmland rented from others & Hectare \\
\hline Main source of income & Agriculture $=1$, otherwise $=0$ & Dummy \\
\hline Main production & wheat $=1$, otherwise $=0$ & Dummy \\
\hline Average wheat production & Farmland covered with wheat & Hectare \\
\hline Number of oxen & Number of owned oxen & Number \\
\hline Credit history & Got credit for last year production $=1$, otherwise $=0$ & Dummy \\
\hline Tractor experience & Last year I used a tractor for plowing $=1$, otherwise $=0$ & Dummy \\
\hline Tractor demand (buying) & I want to buy $=1$, otherwise $=0$ & Dummy \\
\hline Tractor demand (renting) & I want to use rental service $=1$, otherwise $=0$ & Dummy \\
\hline Oxen plow & I want to continue using oxen $=1$, otherwise $=0$ & Dummy \\
\hline
\end{tabular}

the respondents have experience using tractors. Sixty percent of the respondents had received credit in previous years. Even though there is access to credit, some decided not to take it. In some cases, farmers can use the local government office as collateral, and in other cases, they use their farmland and house as collateral to obtain credit.

\subsection{Access to agricultural tractors}

Because of an increase in the feeding and management cost of using animal power for plowing, and also due to the higher efficiency of tractors, the respondents preferred to use agricultural tractors for plowing and transport services either through renting or purchasing, which fits the findings of Takeshima [39]. The descriptive statistics presented in Table 5 show that $41.77 \%$ of the respondents preferred to adopt tractors through purchasing, and 44.3\% preferred using rental services, which is similar to the findings of Takele and Selassie [40]. As discussed in the descriptive statistics, each farm $\mathrm{HH}$ has an average of four oxen and 1.43 transporting animals that can be valued at about ETB 46,000 (USD 2010), which can be used as a source of cash to purchase or rent tractors. The credit institution working around the study area, Amhara Credit and Saving Institution, can also be used as a credit source because it uses land, houses, and oxen as collateral for credit. 
Table 4 Descriptive statistics

\begin{tabular}{|c|c|c|c|c|}
\hline & Mean & SD & Frequency & $\begin{array}{l}\text { Frequency } \\
\text { percentage }\end{array}$ \\
\hline $\mathrm{HH}$ head & & & 76 & 96.20 \\
\hline Type of farmer & & & 65 & 82.28 \\
\hline Family size & 6.64557 & 1.641122 & & \\
\hline Working family size & 2.43038 & 0.710427 & & \\
\hline Information on tractor use & & & 78 & 98.73 \\
\hline Own farm size & 2.009494 & 1.211882 & & \\
\hline Rented farm size & 1.041139 & 0.810024 & & \\
\hline Main source of income & & & 78 & 98.73 \\
\hline Main production & & & 68 & 86.08 \\
\hline $\begin{array}{l}\text { Average wheat production (high, } \\
\text { low wheat producers) }\end{array}$ & $\begin{array}{c}1.482594937 \\
(1.81,1.28)\end{array}$ & 0.77256 & & \\
\hline Number of oxen & 4 & 1.458837 & & \\
\hline Credit history & & & 48 & 60.76 \\
\hline Tractor experience & & & 2 & 0.03 \\
\hline Tractor demand (buying) & & & 33 & 41.77 \\
\hline Tractor demand (renting) & & & 35 & 44.30 \\
\hline Oxen plow & & & 11 & 13.92 \\
\hline
\end{tabular}

Table 5 Tractor adoption by wheat productivity

\begin{tabular}{lclc}
\hline & Tractor purchase (\%) & Tractor rent (\%) & Oxen plow (\%) \\
\hline From total sample & $33(41.77)$ & $35(44.3)$ & $11(13.9)$ \\
From high wheat producers & $30(90.9)$ & $11(31.4)$ & $1(9.1)$ \\
From low wheat producers & $3(9.1)$ & $24(68.6)$ & $10(90.9)$ \\
\hline
\end{tabular}

Table 6 Random Parameter Logit for purchase design

\begin{tabular}{lllcl}
\hline & Coef & SE & z-value & $\operatorname{Pr}(>|z|)$ \\
\hline FW & $1.7405+00$ & $2.6226-01$ & 6.6366 & $3.2090-11^{\mathrm{c}}$ \\
$\mathrm{U}$ & $-1.5254-01$ & $1.6783-01$ & -0.9089 & 0.3634 \\
PO & $2.5470+00$ & $3.1051-01$ & 8.2026 & $2.2200-16^{\mathrm{c}}$ \\
PTO & $4.2941+00$ & $4.6880-01$ & 9.1598 & $2.2000-16^{\mathrm{c}}$ \\
P $_{P}$ & $-1.1670-05$ & $4.6520-06$ & -2.5086 & $0.0121^{\mathrm{a}}$ \\
ASC & $-4.2560-01$ & $8.5664-01$ & -0.4968 & 0.6193 \\
sd.ASC.ASC & $7.1564-01$ & $1.5854+00$ & 0.4514 & 0.6517 \\
\hline
\end{tabular}

Significance codes: ${ }^{\mathrm{a}}$ and ${ }^{\mathrm{C}}$ represent the $10 \%$ and $1 \%$ significance levels, respectively Marginal effect of each variable on the utility function

\subsubsection{Tractor adoption through purchasing}

Table 6 presents the estimated mean values of the parameters used in the purchase design. From the total samples, $41.77 \%$ responded to purchase tractors either as a group or privately using their savings and/or credit. Of these respondents, $90.9 \%$ were from high wheat production kebeles in the study area (Table 5). The high wheat production zone has a characteristically large farm size, higher productivity, higher income, and better savings.

Regarding the purchase-design parameters, the FW, PO, and PTO variables were found to be significant and positive. The price coefficient was found to be significant and negative. As shown in the random parameter logit (RPL) estimation result, farmers in high wheat production areas preferred 4WT with plowing only or plowing and transporting services, either new or used. This is because, in the study area, land preparation requires much of the labor and time of households. The value of the price coefficient shows that demand is expected to change along with marked differences in the unit 
Table 7 Estimated willingness to pay for purchase design

\begin{tabular}{llccc}
\hline & Coef & SE & z-value & $\operatorname{Pr}(>|z|)$ \\
\hline FW & 149,142 & 60,395 & -2.4694 & $0.0135^{\mathrm{a}}$ \\
U & $-13,071$ & 15,123 & 0.8643 & 0.3874 \\
PO & 218,253 & 86,784 & -2.5149 & $0.0119^{\mathrm{a}}$ \\
PTO & 367,957 & 145,118 & -2.5356 & $0.0112^{\mathrm{a}}$ \\
ASC & $-36,469$ & 81,373 & 0.4482 & 0.6540 \\
sd.ASC.ASC & $-61,322$ & 135,442 & -0.4528 & 0.6507 \\
\hline
\end{tabular}

Significance codes: ${ }^{\text {a }}$ represent the $10 \%$ significance level

The estimated willingness to pay for each characteristics of a tractor

\begin{tabular}{lllrl}
\hline & \multicolumn{1}{l}{ Coef } & SE & \multicolumn{1}{c}{$z$-value } & $\operatorname{Pr}(>|z|)$ \\
\hline TW & 0.0495 & 0.1521 & 0.3252 & 0.7450 \\
AH & 0.1531 & 0.1522 & 1.0060 & 0.3144 \\
$P_{R}$ & -0.0041 & 0.0004 & -10.5257 & $2.0000-16^{c}$ \\
ASC & 7.0204 & 0.6838 & 10.2661 & $2.0000-16^{c}$ \\
sd.ASC.ASC & 0.0189 & 0.6049 & 0.0313 & 0.9751 \\
\hline
\end{tabular}

Significance codes: ${ }^{c}$ represent the $1 \%$ significance level

Marginal effect of each variable on the utility function
Table 8 Random Parameter Logit for rental service design prices of each tractor. However, because of the presence of cooperatives working on product marketing, input delivery, and the improvement of rural infrastructure, farmers have devoted little attention to transporting-only tractors [41].

The willingness to pay (WTP) estimation result, presented in Table 7, demonstrates that the respondents valued 4WT at ETB 149,142 (USD 6516), whereas plowing-only tractors were valued at ETB 218,253 (USD 9536). Furthermore, they are willing to pay ETB 367,957 (USD 16,077) for plowing-and-transport tractors. Farmers are also willing to pay for additional services attached to the plowing-type tractor. They are less concerned about the machine condition. In fact, no significant difference was found in the expected service years of the machine presented in the experiment. The standard errors of all significant variables show economic status and preference differences across the respondents in the study area.

Because of efficiency differences between $2 W T$ and $4 W T$, respondents valued $4 W T$ over $2 W T$; $4 W T$ can plow 1 ha in $3 \mathrm{~h}$ and $12 \mathrm{~min}$, whereas a $2 W T$ took $10 \mathrm{~h}$ and $30 \mathrm{~min}$.

\subsubsection{Tractor adoption through rental}

Table 8 presents the estimated coefficients of the rent experiment results. As presented in the table, the value of the ASC is significant and positive, and the rental price is significant and negative. The significance result of the ASC shows the farmers' preferences for renting tractors. Of the total sample, $43.3 \%$ chose to rent tractors. Of these respondents, $71.4 \%$ were from low wheat producing areas (Table 5). The low wheat production zone is characterized by small farm sizes, low productivity, low income, and low savings. Low saving causes an inability to invest in productive assets, including tractors. These farmers preferred to use rental tractors because they have insufficient savings to purchase tractors by themselves. Although opportunities exist to buy the tractors through credit, because of their uncertainty in their repayment ability, they do not choose to use it. Therefore, introducing rental tractors is better for low wheat production areas until they have better savings to cope with uncertainty. Farmers from high wheat producing areas chose to buy tractors, whereas low wheat producers chose to rent tractors. In both cases, the estimation results confirmed that farmers prefer to use agricultural tractors.

A marked change in the price is expected to affect the rental demand for agricultural tractors. Farmers make a decision about renting tractors by comparing the costs of using animal power and other associated returns of the machinery. Therefore, the negative and significant results of the rental price coefficient confirm the inverse relation between the demand to use the tractor and the rental price.

The remaining two coefficients, $\mathrm{TW}$ and $\mathrm{AH}$, were not found to be significant in the rent experiment. For the experiment, it was assumed that the rent service provider could plow the land with acceptable quality. As long as the plow 
work meets the acceptable quality, the rental provider company can use either $2 W T$ or $4 W T$. The payment can be made at any time because subsistence farmers can get access to credit if any cash constraint arises during land preparation. Therefore, the after-harvest payment mode coefficient was not found to be significant.

Table 9 presents the WTP for the non-monetary attributes of renting a tractor for plowing. The values of ASC were found to be significant. The WTP estimation result showed that the per-hectare rental price value for plowing was estimated as ETB 1720 (USD 75). However, the current market rental price is ETB 2000 (USD 87), which is outside of the 99\% confidence interval (1701 and 1739). This result is attributable to the exclusion of high wheat producers in the rent experiment. As discussed above, most rent experiment respondents were low wheat producers, which is a low-income group compared to high wheat producers. Therefore, the expected rental price was found to be less than the current market price. On the other hand, due to the limited supply of tractor rental services, the current price became higher than the amount low wheat producers are willing to pay. Therefore, currently, the low wheat producers, who are not able to pay ETB 2000 (USD 87), could not access rental services. In this case, allowing more rental service companies in the area and introducing tractor dealers could play a significant role in improving the tractor rental supply.

In the case of rental services, the rental provider company is responsible for plowing the land to an acceptable quality. The difference in the type of tractor employed (either 2WT or 4WT) does not change the estimated rental price as long as an acceptable quality of plowing is satisfied. Regarding the payment mode, the value of the after-harvest payment mode did not differ from the interest rate charged by the credit institution near the study area. (ACSI is the only credit institution operating in the study area; it charged an 18\% annual interest rate in 2017).

\subsection{Tractor adoption packages}

The study found that more than $85 \%$ of the respondents wanted to use agricultural tractors either through private ownership or rental services. This can be achieved through government and private sector involvement in the extension service. The following packages should be fulfilled for sustainable agricultural mechanization in the study area:

a. Operator training: Operator training should be included as part of the extension service using the existing farmers' training center. Farmers who want to buy their own tractors should operate them by themselves to minimize unnecessary costs.

b. After-sale service: Spare parts and maintenance services should be available close to the farmers. This could be an employment opportunity for youth groups in the study area.

c. Full-cycle service: In the study area, farmers use oxen power for plowing and threshing. Therefore, in addition to promoting plowing-type tractors, combined harvesters should be promoted through easily accessible farmer cooperatives. In addition, for rental services, a full-cycle plowing service should be included as a package.

d. Infrastructure: Most of the farmlands are fragmented, and there is no road access to reach each piece of farmland to plow with tractors. Therefore, the government should work with farmers to make each plot accessible to tractors.

\section{Conclusion}

This study was conducted to understand the preferences of subsistence farmers for agricultural tractors in the Debre Eliyas district in Ethiopia. The choice experiment estimation result showed that tractors can be introduced to subsistence farmers through rental or direct sales. Due to the heterogeneity in wheat productivity across the district, preferences for types of tractors were found to differ across high and low wheat production zones.

Table 9 Estimated willingness to pay for rental service

\begin{tabular}{lrrrl}
\hline & \multicolumn{1}{c}{ Coef } & \multicolumn{1}{c}{ SE } & z-value & $\operatorname{Pr}(>|z|)$ \\
\hline TW & 12.1167 & 37.2715 & -0.3251 & 0.7451 \\
AH & 37.5188 & 37.3403 & -1.0048 & 0.3150 \\
ASC & $1,719.8600$ & 42.3856 & -40.5765 & $2.0000-16^{c}$ \\
sd.ASC.ASC & -4.6326 & 148.1812 & -0.0313 & 0.9751 \\
\hline
\end{tabular}

Significance codes: ${ }^{c}$ represent the $1 \%$ significance level The estimated willingness to pay for each characteristics of a tractor 
The RPL estimation results demonstrate that farmers living in high wheat production zones prefer to buy their own tractors to be operated by themselves, whereas farmers in the low wheat production zone chose to rent tractors. In the purchase design, the plowing variable was found to be the major criterion for tractor selection. In the experiment, 4WT with both plowing and transport services showed a higher probability of selection, and the highest willingness to pay was found for tractors of this type.

Conversely, farmers living in the low wheat production zone preferred to use rental tractors because of their poor economic position relative to the high production zone. The current rental price was found to be far from the $95 \%$ confidence interval of the estimation result.

The study was limited to small sample size and a specific district in northwest Ethiopia. Further investigation from relatively wider area coverage throughout the country using bigger sample size may enhance our understanding on farmers tractors preference.

\section{Recommendations}

In Ethiopia, increasing agricultural productivity is a major target to be addressed, as stated globally in the UN's SDGs and locally in Ethiopia's Growth and Transformation Plan II. This can be achieved by using improved seeds, promoting landintensive agriculture, and improving labor productivity. Our research was devoted to understanding the preferences of farm households for agricultural tractors.

This study confirmed that subsistence farmers in the study area are interested in using agricultural tractors for plowing and transport. Compared to animal power, subsistence farmers choose agricultural tractors because of their better efficiency and cost effectiveness. Tractors help them shorten the land preparation period, which usually takes half a year. It promotes land-intensive agriculture, allowing farmers to engage in other IGAs, which diversifies their sources of income. Therefore, the government should promote and encourage an appropriate use of tractors that are affordable for subsistence farmers. Encouraging local small enterprises and private investors to provide tractor rental and sales services, strengthening farmers' cooperatives, implementing duty-free import policies for agricultural machinery, and creating credit access with reasonable interest rates are some options that demand consideration.

Additionally, encouraging research centers to promote short-cycled improved seeds should also be accorded similar attention. Short-cycle improved seeds facilitate land-intensive agriculture. The introduction of these technologies is expected to boost agricultural production in the country. Although increased production size has positive effects on food self-sufficiency, creating better market linkages with the outside world can protect farmers from price collapses.

Policymakers should design strategies to absorb the labor that is expected to be displaced from the agricultural sector into agricultural product processing industries or the non-agricultural sector to maintain social welfare. Empowering local youths to become involved in tractor rental services, training farmers about value-added agricultural products, and introducing labor-intensive agricultural product processing industries are some avenues for absorbing displaced labor.

On the other hand, inappropriate and over-use of agricultural machineries may disrupt biodiversity and natural biological process. Therefore, practicing conservative agriculture helps to minimize the soil biodiversity damages.

Acknowledgements I would like to give my first and foremost gratitude to the Almighty God and his mother. Next, I am grateful to all my family members for their priceless support and appreciation. Third, I am greatly indebted to Dr. Hisato SHUTO, your constructive comments and advice made my research more interesting. I am also thankful to Mr. Hiroyuki Ishizaki, Managing Director of Brainstorm Worldwide Inc., for his inviolable support. Further, my appreciation goes to the staff in the Debre Eliyas office of Agriculture, especially Mr. Endazeze Godie, Mr. Asres Bekele, Mr. Yitayal Wubante, and Mr. Mehari Tsegaye, for their kind cooperation, starting from the questionnaire development to the final data collection. Mr. Minyamir Abayineh, the Chief Administrator of the Debre Eliyas District, played a significant role in coordinating staff at the district and community levels from the pre-test to the final survey. Finally, I greatly appreciate the effort of Mr. Wubamlak Andualem for his facilitation during the questionnaire pretest. This study was funded by JSPS KAKENHI, grant number JP19H00960 and JP16H02572.

Authors' contributions All authors contributed on the conceptualization, method of analysis, result interpretations and final report of the study. All authors read and approved the final manuscript.

Funding His study was funded by JSPS KAKENHI, grant number JP19H00960 and JP16H02572.

Availability of data and materials A portion of the data we used in this research is available upon request from the corresponding author after the date of publication. The raw data cannot be made publicly available due to third-party restrictions and because private information of the research participants is included in the data. 
Code availability Not applicable.

\section{Declarations}

Competing interests There are no conflicts of interest to declare.

Open Access This article is licensed under a Creative Commons Attribution 4.0 International License, which permits use, sharing, adaptation, distribution and reproduction in any medium or format, as long as you give appropriate credit to the original author(s) and the source, provide a link to the Creative Commons licence, and indicate if changes were made. The images or other third party material in this article are included in the article's Creative Commons licence, unless indicated otherwise in a credit line to the material. If material is not included in the article's Creative Commons licence and your intended use is not permitted by statutory regulation or exceeds the permitted use, you will need to obtain permission directly from the copyright holder. To view a copy of this licence, visit http://creativecommons.org/licenses/by/4.0/.

\section{References}

1. Gollin D. Smallholder agriculture in Africa: an overview and implications for policy (IIED Working Paper). International institute for environment and development. London: 2014.

2. Solomon D, Lehmann J. Socio-economic scenarios of low hanging fruits for developing climate-smart biochar systems in Ethiopia: Biomass resource availability to sustainably improve soil fertility, agricultural productivity and food and nutrition security. Federal Institute for Geosciences and Natural Resources (BGR-Germany). 2017; https://hdl.handle.net/1813/55321

3. Ethiopian EP. Ethiopia's Climate-Resilient Green Economy (CRGE). Addis Ababa: Federal Democratic Republic of Ethiopia; 2011. p. 188.

4. Moyo S. Family farming in sub-Saharan Africa: its contribution to agriculture, food security and rural development (Working paper number 150). Brasilia: International Policy Centre for Inclusive Growth (IPC-IG). 2016.

5. UN General Assembly. Sustainable Development Goals (SDGs): transforming our world: The 2030 agenda for sustainable development. New York: United Nations; 2015.

6. Ethiopia National Planning Commission. Growth and Transformation Plan-II (2015/16-2019/20). Vol. I:The main text. Addis Ababa, Ethiopia. 2015.

7. Ministry of Agriculture (MoA) and Agricultural Transformation Agency (ATA). Ethiopian national agricultural mechanization strategy: Vision, systemic challenges and strategic interventions. Working document. 2014.

8. Agricultural Transformation Agency (ATA). Mechanization. 2017. http://www.ata.gov.et/programs/mechanization. Accessed 20 Aug 2017.

9. Ministry of Finance and Economic Development (MoFED). Rural development policy and strategies. Addis Ababa, Ethiopia. 2003.

10. Davis B, Winters P, Carletto C, Covarrubias K, Quiñones EJ, Zezza A, Stamoulis K, Bonomi G, Di Giuseppe S. Rural income generating activities: a cross country comparison. Background paper for the World Development Report. 2008; https://doi.org/10.2139/ssrn.3307433

11. Pingali P. Agricultural mechanization: adoption patterns and economic impact. Handb Agric Econ. 2007;1(3):2779-805. https://doi. org/10.1016/S1574-0072(06)03054-4.

12. Owombo PT, Akinola AA, Ayodele OO, Koledoye GF. Economic impact of agricultural mechanization adoption: evidence from maize farmers in Ondo State, Nigeria. J Agric Biodiver Res. 2012;1(2):25-32.

13. Paudel GP, Kc DB, Khanal NP, Justice SE, McDonald AJ. Smallholder farmers' willingness to pay for scale-appropriate farm mechanization: evidence from the mid-hills of Nepal. Technol Soc. 2019;59:101196. https://doi.org/10.1016/j.techsoc.2019.101196.

14. Kahan D, Bymolt R, Zaal F. Thinking outside the plot: insights on small-scale mechanisation from case studies in East Africa. J Develop Stud. 2018;54(11):1939-54. https://doi.org/10.1080/00220388.2017.1329525.

15. Goe MR. Animal Traction on Smallholder Farms in the Ethiopian Highlands [PhD thesis]. Ithaca, NY: Department of Animal Science. Ithaca, NY: Cornell University. 1987.

16. Cohen JM. Effects of green revolution strategies on tenants and small-scale landowners in the Chilalo region of Ethiopia. J Develop Areas. 1975;9(3):335-58.

17. Kelemu F. Agricultural mechanization in Ethiopian: experience, status and prospects. Ethiopian J Agric Sci. 2015;25(1):45-60.

18. Mutua J, Kaumbutho P, Mung'oo J. Market analysis for small mechanization-Kenya. Farm Mechanization and Conservation Agriculture for Sustainable intensification Project. CIMMYT International Maize and Wheat Improvement Centre. 2014.

19. Assefa $A$, Liben $M$, Yeshalem B. The effect of tillage frequency and weed control on yield of tef (Eragrostis tef) in Yielmana-Densa Area, northwestern Ethiopia. East Afr J Sci. 2008;2(1):35-40. https://doi.org/10.4314/eajsci.v2i1.40362.

20. Temesgen M, Rockstrom J, Savenije HH, Hoogmoed WB, Alemu D. Determinants of tillage frequency among smallholder farmers in two semi-arid areas in Ethiopia. Phys Chem Earth, Parts A/B/C. 2008;33(1-2):183-91. https://doi.org/10.1016/j.pce.2007.04.012.

21. Tadesse W, Bishaw Z, Assefa S. Wheat production and breeding in Sub-Saharan Africa. Int J Clim Change Strat Manage. 2019;11(5):696-715. https://doi.org/10.1108/IJCCSM-02-2018-0015.

22. Bardhan P, Udry C. Development microeconomics. Oxford: OUP; 1999.

23. Basu S, Kimball M. Long-run labor supply and the elasticity of intertemporal substitution for consumption. Manuscript, University of Michigan. 2002.

24. Guerron-Quintana PA. Refinements on macroeconomic modeling: The role of non-separability and heterogeneous labor supply. J Econ Dynam Control. 2008;32(11):3613-30. https://doi.org/10.1016/j.jedc.2008.01.008.

25. Sorensen JB. Endogeneity is a fancy word for a simple problem. Unpublished. Google Scholar. 2012.

26. Louviere JJ, Hensher DA, Swait JD. Stated choice methods: analysis and applications. Cambridge: Cambridge University Press; 2000. 
27. Pan D, Zhou G, Zhang N, Zhang L. Farmers' preferences for livestock pollution control policy in China: a choice experiment method. J Clean Prod. 2016;10(131):572-82. https://doi.org/10.1016/j.jclepro.2016.04.133.

28. Blazy JM, Carpentier A, Thomas A. The willingness to adopt agro-ecological innovations: application of choice modelling to Caribbean banana planters. Ecol Econ. 2011;15(72):140-50. https://doi.org/10.1016/j.ecolecon.2011.09.021.

29. Breustedt G, Müller-Scheeßel J, Latacz-Lohmann U. Forecasting the adoption of GM oilseed rape: evidence from a discrete choice experiment in Germany. J Agric Econ. 2008;59(2):237-56. https://doi.org/10.1111/j.1477-9552.2007.00147.x.

30. Lambrecht I, Vranken L, Merckx R, Vanlauwe B, Maertens M. Ex ante appraisal of agricultural research and extension: a choice experiment on climbing beans in Burundi. Outlook Agric. 2015;44(1):61-7. https://doi.org/10.5367/oa.2015.0199.

31. Rigby D, Burton MP. Capturing preference heterogeneity in stated choice models: a random parameter logit model of the demand for GM food (No. 414-2016-26059). In, Australian Agricultural and Resource Economics Society (AARES) 2003 Conference (47th). February 12-14, 2003. Fremantle, Australia. 2003; https://doi.org/10.22004/ag.econ.58200

32. Train KE. Recreation demand models with taste differences over people. Land economics. 1998;1:230-9. https://doi.org/10.2307/31470 53.

33. Train KE. Discrete choice methods with simulation. Cambridge: Cambridge University Press; 2009.

34. Croissant Y. mlogit: multinomial logit model. R package version 0.2-4. R Foundation for Statistical Computing: Vienna. 2013.

35. Therneau T. A package for survival analysis in S. (R package version 2.37-7). 2014.

36. Sarrias M, Daziano R. Multinomial logit models with continuous and discrete individual heterogeneity in R: the gmnl package. J Stat Softw. 2017;79(2):1-46. https://doi.org/10.18637/jss.v079.i02.

37. Sarrias M, Daziano R, Yves C. Multinomial Logit Models with Random Parameters (Version 1.1-3). 2017.

38. Aizaki H. Support. CEs: Basic Functions for Supporting an Implementation of Choice Experiments. Comprehensive R Archive Network. 2014.

39. Takeshima H. Custom-hired tractor services and returns to scale in smallholder agriculture: a production function approach. Agric Econ. 2017;48(3):363-72. https://doi.org/10.1111/agec.12339.

40. Takele A, Selassie YG. Socio-economic analysis of conditions for adoption of tractor hiring services among smallholder farmers, Northwestern Ethiopia. Cogent Food Agric. 2018;4(1):1453978. https://doi.org/10.1080/23311932.2018.1453978.

41. Bernard T, Spielman DJ. Reaching the rural poor through rural producer organizations? A study of agricultural marketing cooperatives in Ethiopia. Food Policy. 2009;34(1):60-9. https://doi.org/10.1016/j.foodpol.2008.08.001.

Publisher's Note Springer Nature remains neutral with regard to jurisdictional claims in published maps and institutional affiliations. 